\title{
Revisão das espécies sul-americanas de Euhybus (Diptera, Hybotidae, Hybotinae) do grupo purpureus
}

\author{
Rosaly Ale-Rocha
}

Coordenação de Pesquisas em Entomologia, Instituto Nacional de Pesquisas da Amazônia, Caixa Postal 478, 69011-970 Manaus, AM, Brasil. (alerocha@inpa.gov.br)

\begin{abstract}
Revision of the South American species of Euhybus (Diptera, Hybotidae, Hybotinae), of the purpureus species-group. The South American species of Euhybus Coquillett, 1895 (Diptera, Hybotidae, Hybotinae) of the purpureus species-group are reviewed. A diagnosis for this group of species is presented and six new species are described: E. fuscipennis, E. grandis, E. novoaripuanensis, E. niger, E. reduncus and E. tomentosus. New records are made and the relationships of the purpureus species-group with other species-groups of Euhybus are discussed.
\end{abstract}

KEYWORDS. South America, taxonomy, identification key, new species, Euhybus.

\section{INTRODUÇÃO}

Euhybus Coquillett, 1895 é um gênero diversificado, que inclui espécies medindo 3 a $7 \mathrm{~mm}$ de comprimento, corpo castanho-claro a preto, asa geralmente larga com lobo anal triangular e base mais escura, escuto com cerdas numerosas, raramente esparsas. Os adultos são distinguidos de outros Hybotinae pela arista nua, apical; flagelo oval; olhos holópticos ou face linear; probóscide curta com labelo membranoso, pseudotraquéias presentes; um par de cerdas ocelares; tórax fortemente arqueado com as cerdas posteriores proclinadas; pronoto longo; veia Rs curta; R4+5 e M1 convergentes, raramente paralelas; $8^{\circ}$ segmento abdominal do macho com giro de $45^{\circ}$ para a direita e terminália masculina assimétrica.

Coquillett (1895) estabeleceu o gênero Euhybus para incluir três espécies descritas em Hybos Meigen, 1803 por WaLKer (1849): H. purpureus, H. subjectus e $H$. triplex. Melander (1902) designou H. purpureus como a espécie-tipo de Euhybus. Euhybus ocorre exclusivamente nas Américas e inclui até o presente 56 espécies (Melander, 1965; Smith, 1967; Ale-Rocha, 2002).

O conhecimento acerca da diversidade deste gênero é resultante das contribuições de WheELER \& Melander (1901), Bezzi (1909), Melander (1927), Curran (1931) e Smith (1963). Mais recentemente, Rafael \& AleRocha (1995) revisaram os tipos de Bezzi e Ale-Rocha (2002) arranjou as espécies de Euhybus em cinco grupos informais com base em caracteres da asa e da terminália masculina e feminina: grupos E. dimidiatus, E. purpureus, E. hallexus, E. crassipes e E. neotropicus. Destes, o grupo hallexus foi recentemente elevado ao status de gênero (Ale-Rocha \& CARvalho, 2003).

Neste trabalho, as espécies sul-americanas do grupo purpureus são revisadas; seis espécies novas são descritas, uma diagnose do grupo é apresentada e novos registros geográficos são feitos. As relações do grupo purpureus com outros grupos de espécies de Euhybus são discutidas e uma chave para os grupos de espécies de Euhybus é apresentada, bem como para as espécies sul-americanas do grupo purpureus.

\section{MATERIAL E MÉTODOS}

A terminália foi removida do abdome, macerada com ácido lático quente $85 \%$ de acordo com Cumming (1992), e acondicionada em microtubo de plástico com glicerina. As asas foram retiradas do corpo e montadas entre lamínulas. Os microtubos e as lamínulas foram afixados no mesmo alfinete do espécime correspondente.

O material estudado está depositado nas seguintes instituições: The Natural History Museum, Londres, Inglaterra (BMNH); Instituto Nacional de Pesquisas da Amazônia, Manaus, Brasil (INPA); Museu de Zoologia da Universidade de São Paulo, São Paulo, Brasil (MZSP); American Museum of Natural History, Nova Iorque, E.U.A. (AMNH); Museu Paraense Emílio Goeldi, Belém, Brasil (MPEG); Zentralinstitut Museum für Naturkunde, Humboldt Universität, Berlim, Alemanha (ZMHU).

A terminologia usada nas descrições segue McAlpine (1981), exceto para a terminália masculina, em que foi seguida a terminologia de Cumming et al. (1995). Abreviaturas utilizadas: A, anterior; acr, acrostical; AD, ântero-dorsal; AV, ântero-ventral; $\mathrm{D}$, dorsal; dc, dorsocentral; npl, notopleural; P, posterior; PD, póstero-dorsal; $\mathrm{PV}$, póstero-ventral; $\mathrm{St}$, esternito; $\mathrm{Tg}$, tergito; $\mathrm{V}$, ventral.

Uma diagnose reúne o conjunto de caracteres que distingue o grupo purpureus, evitando a repetição dos caracteres comuns do grupo nas descrições das espécies. Chave para os grupos de espécies de Euhybus, bem como para as espécies do grupo purpureus, são fornecidas.

Chave para os grupos de espécies de Euhybus

1. Célula costal estreita; coloração da asa variável ..... 2 Célula costal larga; base da asa mais escura que o ápice

2. Asa hialina ou suavemente e homogeneamente tingida; lobo anal discretamente desenvolvido, frequentemente com margem suavemente arredondada; cerdas do escuto esparsas

grupo neotropicus

Asa mais escura na base; lobo anal desenvolvido, triangular; cerdas do escuto numerosas 
grupo crassipes

3. Asa algo curta, no máximo duas vezes mais longa do que larga; margem da célula costal com forte elevação próximo da veia humeral ....

grupo dimidiatus

Asa alongada, pelo menos 2,5 vezes mais longa que larga; margem da célula costal apenas suavemente convexa, quase reta grupo purpureus

\section{Grupo purpureus}

Diagnose. Os membros desse grupo são caracterizados pelos olhos holópticos a estreitamente dicópticos na face; cerdas occipitais alongadas, pósoculares dobradas para frente; escuto cerdoso, cerdas acr e dc multisseriadas; pronoto, escuto e escutelo brilhantes dorsalmente [exceto E. piceus (Wiedemann, 1830) e E. tomentosus sp. nov. com dorso do tórax pruinoso]; notopleura, disco pré-escutelar, margem do pronoto e escutelo pruinosos; mesopleura pruinosa com áreas nuas, sem pruinosidade; asa larga, célula costal larga, margem da célula costal reta ou levemente convexa, base da asa mais escura que o ápice, lobo anal largo, triangular.

Discussão. O grupo purpureus parece ser mais próximo do grupo dimidiatus. Ambos compartilham a asa larga com a base mais escura que o ápice, célula costal alargada e lobo anal desenvolvido. Podem ser distinguidos entre si pela asa mais alongada com a margem costal quase reta no grupo purpureus e pela asa triangular com célula costal fortemente convexa perto da base, no grupo dimidiatus.

Chave para as espécies sul-americanas de Euhybus do grupo purpureus

1. Pterostigma fraco, sub-hialino (fig. 66); tíbia posterior com face PV ligeiramente escavada e faces $\mathrm{V}$ e $\mathrm{P}$ em forma de quilha; surstilo direito longo, delgado, dobrado ao meio para dentro, em ângulo quase reto (figs. 45, 46); hipândrio fortemente estreitado no meio (fig. 49); segmento 8 do ovipositor levemente assimétrico, com torção para a esquerda, as faces dorsal e ventral quase completamente membranosas (figs. 50, 51)

E. reduncus sp.nov.

Pterostigma distinto (figs. 60-65), castanho; tíbia posterior variável, terminália masculina e feminina não como acima

2(1). Escuto pruinoso dorsalmente ........................... 3

Escuto brilhante dorsalmente, pruinosidade restrita às margens do escuto ...................................... 4

3(2). Tíbia posterior tubular, levemente falciforme, com uma cerda D pré-apical fracamente destacada; margem da célula costal convexa (fig. 67); abdome robusto; surstilo direito longo, maior que metade do comprimento do epândrio, levemente curvado para dentro (figs. 52, 53); surstilo esquerdo com ápice largo e truncado (fig. 54) ..

E. tomentosus sp.nov.

Tíbia posterior tubular, reta, sem cerdas destacadas; margem da célula costal reta (fig. 65); abdome delgado; surstilo esquerdo estreitado e alongado, bífido distalmente, com dois prolongamentos digitiformes divergentes (fig. 40); margem ventral da lamela epandrial esquerda com numerosas cerdas longas na porção mediana (fig. 38); lobo hipandrial direito com dilatação pré-apical na margem lateral interna (fig. 41) ........... E. piceus

4(2). Tíbia posterior tubular, porção submediana dilatada com uma concavidade oval na face ventral; fêmur posterior com semicírculo de espinhos no 1/3 apical; lobo hipandrial esquerdo tão longo quanto o direito, lobo direito com ápice afilado; surstilo esquerdo dividido em dois processos largos, sendo o látero-dorsal vertical e o látero-ventral perpendicular e curvado para dentro (fig. 10); surstilo direito falciforme e curto (figs. 9 , 11) ................................... E. grandis sp.nov.

Tíbia e fêmur posteriores não como acima .......... 5

5(4). Tíbia posterior tubular; escuto com cerdas alongadas, as anteriores quase eretas; fêmur posterior moderadamente alargado; surstilo esquerdo estreitado e prolongado distalmente; margem ventral da lamela epandrial esquerda com numerosas cerdas longas na porção mediana (fig. 2); lobo hipandrial direito com dilatação pré-apical na margem lateral interna (fig. 5); ovipositor com pequena área circular, esclerotizada, na membrana ventral entre o segmento 7 e 8 (fig. 7)

E. fuscipennis sp.nov.

Tíbia posterior achatada ântero-posteriormente; escuto com cerdas muito curtas, as anteriores fortemente inclinadas para trás; fêmur posterior fortemente dilatado no meio, com a face ventral larga e aplainada; terminália masculina e feminina não como acima

6(5). Lobo hipandrial direito estreito (fig. 25); surstilo direito longo, com superfície interna côncava, ápice largo, com 3 pontas curtas (fig. 22, 24); esclerito basciliforme direito com uma projeção sub-basal delgada, vertical, quase reta (fig. 21)

E. niger sp.nov

Lobo hipandrial direito alargado; surstilo direito longo ou curto, com protuberâncias ou projeções na face interna e/ou dorsal, ápice bifurcado; projeção sub-basal do esclerito baciliforme direito curva ................................................ 7

7(6). Lobo hipandrial direito pouco mais longo que a base do hipândrio, largo com a base estreitada e ápice arredondado (fig. 20); surstilo direito com protuberâncias na face interna e dorsal (figs. 16,17); esclerito baciliforme com um processo delgado, horizontal com ápice reto, logo abaixo dos cercos (fig. 16) ................ E. makauriensis

Lobo hipandrial direito mais curto que a base do hipândrio, base tão larga quanto o ápice, ápice truncado (fig. 33); surstilo direito com face ventral lisa (fig. 30); processo do esclerito baciliforme horizontal, com ápice curvado para baixo (fig. 29) ........ E. novoaripuanensis sp.nov. 


\section{Euhybus fuscipennis sp. nov.}

(Figs. 1-9, 62)

Diagnose. Escuto brilhante dorsalmente, com cerdas delgadas, alongadas e castanhas; asa castanha, clareando gradualmente em direção ao ápice, pterostigma castanho; tíbia posterior reta, tubular, sem cerdas destacadas; surstilo esquerdo estreitado e prolongado distalmente; margem ventral da lamela epandrial esquerda com numerosas cerdas longas na porção mediana; lobo hipandrial direito com dilatação pré-apical na margem lateral interna.

Holótipo macho. Dimensões, em mm: corpo 5,0; asa 4,6. Flagelo oval, 2,5 vezes mais longo que largo, pouco mais longo que o escapo e o pedicelo combinados.

Tórax castanho a castanho-escuro; escuto brilhante no dorso, com pruinosidade restrita à notopleura, disco pré-escutelar e escutelo; pleuras pruinosas, exceto anepisterno e catepisterno brilhantes, com pruinosidade somente nas margens. Escuto com cerdas delgadas, castanhas, densas, alongadas anteriormente, cerdas do disco pré-escutelar aproximadamente 1,5 vezes mais longas que as anteriores; acr com 8-10 filas; notopleura cerdosa, com 3 npl longas, a posterior mais fraca. Escutelo com 7-8 pares de cerdas sendo um par apical longo, forte e paralelo, um par subapical forte e cerca de $3 / 4$ do comprimento do par apical e 5-6 cerdas laterais delgadas, cerca de 1/3 do comprimento do par de apical.

Asa (fig. 62) castanha, clareando gradualmente e suavemente em direção ao ápice, pterostigma castanho; célula costal mais larga que a r1, suavemente côncava.

Pernas com cerdas de revestimento castanhas. Todas as pernas castanhas, exceto a tíbia anterior e média e os dois primeiros tarsômeros de todas as pernas, castanho-claros a amarelos. Fêmur posterior 5 vezes mais longo que largo. Tíbia posterior reta, tubular. Cerdas destacadas: tíbia anterior com $1 \mathrm{~A}$ pré-apical curta, não alcançando a metade do comprimento do primeiro tarsômero. Tíbia média com cerdas AD delgadas, sendo as duas cerdas basais mais robustas que as demais, a basal cerca de 1,5 vezes mais longa que a seguinte; $1 \mathrm{~V}$ pré-apical longa, alcançando a metade do comprimento do primeiro tarsômero. Primeiro tarsômero médio com uma cerda PV sub-basal longa, alcançando seu ápice. Trocanter posterior com 2 espinhos ventrais fortes. Fêmur posterior com uma cerda AD no 1/5 apical; $1 \mathrm{~A}$ pré-apical; série AV com 9 cerdas espiniformes; série $\mathrm{V}$ com 6 cerdas desenvolvidas, na metade basal do fêmur e 6 espinhos curtos, no $1 / 3$ apical, porção média da superfície ventral nua; série PV com 9 cerdas espiniformes. Tíbia e tarso posterior sem cerdas destacadas.

Abdômen 2,5 vezes mais longo que o tórax, castanho com brilho metálico azulado; Tg8 com pruinosidade castanha; tergitos 1-3 com cerdas castanhas longas e densas, cerdas dorsais inconspícuas. Terminália (figs. 1-7): surstilo esquerdo estreitado e prolongado distalmente; margem ventral da lamela epandrial esquerda com numerosas cerdas longas na porção mediana; lobo hipandrial direito com dilatação pré-apical na margem lateral interna.
Fêmea. Semelhante ao macho exceto: trocanter posterior sem espinho; fêmur posterior delgado com cerdas destacadas mais esparsas, 8 cerdas AV mais finas e longas que no macho, série $\mathrm{V}$ com 9 espinhos curtos, na metade apical do fêmur, uma cerda na porção média e uma cerda mais forte, no $1 / 3$ basal; série PV com 3 cerdas no 1/4 apical. Ovipositor como nas figuras 8 e 9 .

Material-tipo. Holótipo ơ, BRASIL, São Paulo: Salesópolis (Estação Biológica Boracéia), I.1949, M. P. Barreto col. (MZSP) (em bom estado, não dissecado). Parátipos. Santa

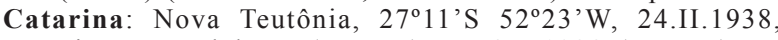
espécime sem abdome (BMNH); đ', 6.X.1938 (BMNH); శ’, 9.XI.1938 (BMNH); São Paulo: Salesópolis (Estação Biológica Boracéia), ơ, IX.1948 (INPA); idem, 2 f, IX.1949 (MZSP, INPA); Cantareira, Chapadão, 2 đ', IX.1946; đ', II.1946; 20 \&, IX.1949 (MZSP); \&, VIII.1949 (INPA); Horto Florestal, ơ, 13.II.1949, Ramalho col. (INPA); Campos do Jordão (Engenheiro Lefevre), 1200 m, ơ, 22.III.1963, Guimarães col. (MZSP).

Distribuição. Brasil (São Paulo, Santa Catarina).

Discussão. Espécie semelhante a E. piceus no aspecto geral da terminália masculina, porém pode ser separada pelo surstilo esquerdo com margem apical inteira, escuto sem pruinosidade dorsal, cerdas do escuto castanhas, cerdas do disco pré-escutelar 1, 5 vezes mais longas que as anteriores e escutelo com 7 a 8 pares de cerdas.

Etimologia. O nome específico refere-se à coloração da asa.

\section{Euhybus grandis sp. nov.}

(Figs. 10-17, 63)

Diagnose. Escuto brilhante dorsalmente, com cerdas curtas e castanhas; asa castanha com ápice castanho-claro; pterostigma castanho; primeiro tarsômero posterior com um espinho AV apical; tíbia posterior tubular, sem cerdas destacadas, porção submediana dilatada com uma concavidade oval na face ventral; fêmur posterior com semicírculo ventral de espinhos no $1 / 3$ apical que se encaixam no sulco ventral da tíbia; lobo hipandrial esquerdo tão longo quanto o direito, lobo direito com ápice afilado; surstilo esquerdo dividido distalmente em dois processos largos, sendo o láterodorsal vertical e o látero-ventral perpendicular e curvado para dentro; surstilo direito falciforme e curto.

Holótipo macho. Dimensões, em mm: corpo 6,9; asa 5,8. Flagelo oval, duas vezes mais longo que largo, 1,4 vezes mais longo que o escapo e o pedicelo juntos.

Tórax castanho a preto; escuto brilhante no dorso, com pruinosidade restrita à notopleura, disco préescutelar e escutelo; pleura pruinosa, brilhante na região central do anepisterno e catepisterno. Escuto com cerdas curtas e castanhas; acr com 6-8 séries; 3 npl; cerdas do disco pré-escutelar cerca de 1,5 vezes mais longas que as anteriores. Escutelo com 5 pares de cerdas sendo um par apical longo e divergente, um par subapical convergente cerca de metade do comprimento do par apical e 3 cerdas laterais curtas e delgadas.

Asa (fig. 63) castanha nos $2 / 3$ basais e ápice castanho-claro; pterostigma castanho-escuro com halo hialino; margem da célula costal levemente convexa na porção basal.

Pernas com cerdas de revestimento castanhas. 


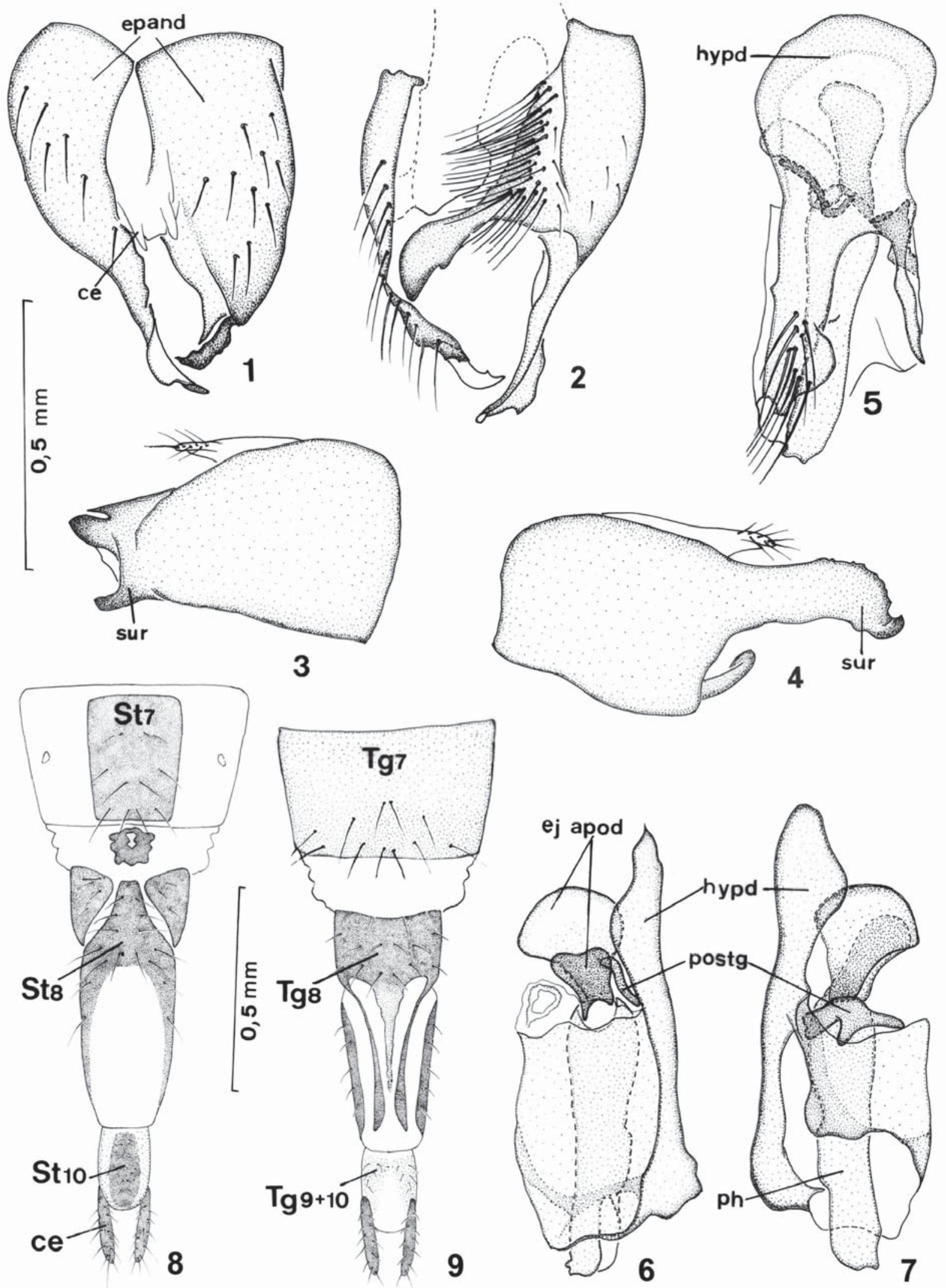

Figs. 1-9. E. fuscipennis sp. nov. Parátipo o: 1, 2, epândrio, vista dorsal e ventral; 3, 4, lamela epandrial direita e esquerda; hipândrio: 5 , vista ventral; 6 , 7, vista lateral direita e esquerda, respectivamente. Parátipo 5 : 8, ovipositor, vista ventral; 9 , dorsal (ce, cercos; ej apod, apódema ejaculador; epand, epândrio; hypd, hipândrio; ph, falo; postg, posgonito; St, esternito; Tg, tergito; sur, surstilo). Figs. $1-7,8-9$ na mesma escala. 


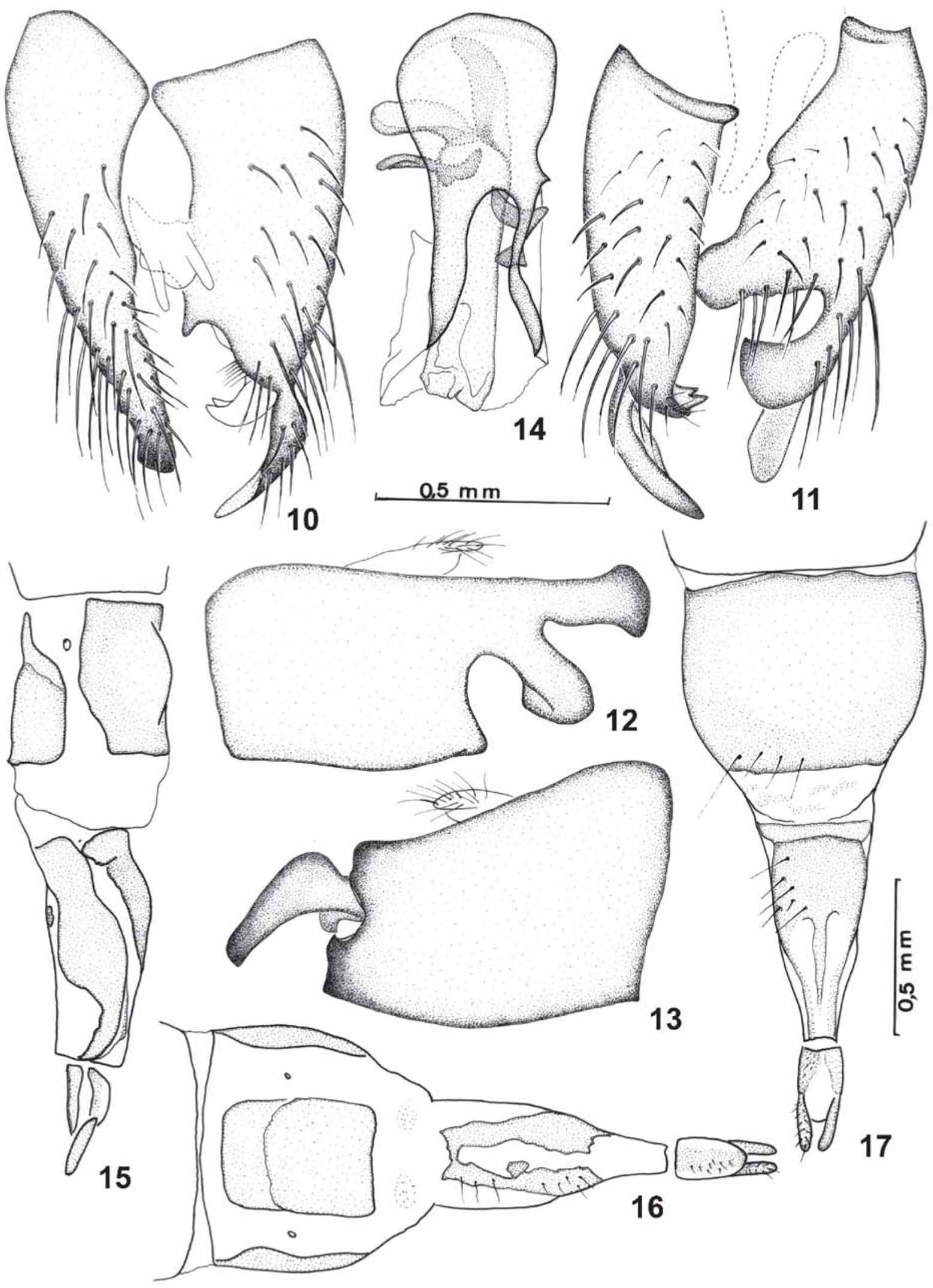

Figs. 10-17. E. grandis sp. nov. Parátipo ơ: 10, 11, epândrio, vista dorsal e ventral; 12, 13, lamela epandrial esquerda e direita; 14 hipândrio, vista ventral. Parátipo §: 15 , ovipositor, vista dorsal; 16, ventral; 17, lateral. Figs 10-14, 15-17 na mesma escala. 
Coxas, trocanteres e fêmures posteriores castanhoescuros; fêmures anterior e médio com ápice castanhoclaro; tíbias castanho-claras; primeiro e segundo tarsômeros amarelos, os demais castanhos. Fêmur posterior 4,5 vezes mais longo que largo. Tíbia posterior tubular, porção submediana dilatada com uma concavidade oval na face ventral onde se encaixam os espinhos do fêmur posterior, quando flexionada. Cerdas destacadas: tíbia anterior com 1A e 1P pré-apicais curtas, não alcançando a metade do primeiro tarsômero. Tíbia média com 4AD igualmente curtas; $1 \mathrm{~V}$ apical curta, não alcançando a metade do primeiro tarsômero. Primeiro tarsômero médio com 3 cerdas PV curtas (uma sub-basal; uma pré-apical; uma no $1 / 3$ basal mais longa, mas não alcança o ápice do tarsômero). Trocanter posterior com 3 espinhos V. Fêmur posterior com duas cerdas AD no 1/4 apical e 1AD mediana; 6A nos 2/3 apicais; $11 \mathrm{AV} ; 9 \mathrm{~V}$ nos $2 / 3$ basais e 6 a 7 espinhos curtos com bases protuberantes organizadas em um semicírculo no $1 / 3$ apical; face PV com 5 cerdas curtas na metade basal, 5 tubérculos organizados em um semicírculo no $1 / 3$ apical, 2 espinhos próximos do ápice e um espinho curto, apical. Tíbia posterior sem cerdas dorsais destacadas.

Abdômen 2,7 vezes o comprimento do tórax, com cerdas amarelas delgadas; castanho; Tg8 com pruinosidade castanha. Terminália (figs. 10-14): lobo hipandrial esquerdo tão longo quanto o direito, lobo direito com ápice afilado; surstilo esquerdo dividido distalmente em dois processos largos, sendo o láterodorsal vertical e o látero-ventral perpendicular e curvado para dentro; surstilo direito falciforme e curto.

Fêmea. Similar ao macho exceto por: trocanter posterior com 2-3 espinhos; fêmur posterior 5,7 vezes mais longo que largo com uma cerda $\mathrm{AD}$ no $1 / 5$ apical, $4 \mathrm{~A}$ na metade apical, $12 \mathrm{AV}, 12$ espinhos $\mathrm{V}$, sendo os 8 apicais mais aproximados, alinhados e mais curtos que os basais, 12 espinhos PV alinhados; tíbia posterior com quilha suave na face ventral. Ovipositor como nas figuras 15-17.

Material-tipo. Holótipo ơ, BRASIL, São Paulo: Cajuru (Cássia dos Coqueiros), IX.1954, M. P. Barreto col. (MZSP) (em bom estado, não dissecado). Parátipos. Goiás: Corumbá, F. Monjolinho, 2 \&, XI.1945, Barreto col. (MZSP); São Paulo: Praia Grande, Faz. Rondonia, \&, I.1945, M. Carrera col. (INPA); Itaporanga, N.B. Antonina, \&, I.1946, Barreto col. (MZSP); Cajuru (Cássia dos Coqueiros), 2 §, \&, IX.1954, M. P. Barreto col. (MZSP); 3 ॐ, 2 क (INPA)

Distribuição. Brasil (Goiás, São Paulo).

Discussão. Espécie muito distinta de todas as outras do grupo pelo tamanho grande, tíbia posterior com porção submediana dilatada com uma concavidade oval na face ventral e fêmur posterior com semicírculo de espinhos no $1 / 3$ apical da face ventral.

Etimologia. O nome específico refere-se ao tamanho da espécie, a maior do grupo.

\section{Euhybus makauriensis Smith, 1963}

(Figs. 18- 22, 64)

Euhybus makauriensis Sмітн, 1963:158, fig.8; 1967:12 (cat.).

Diagnose. Escuto brilhante dorsalmente, com cerdas curtas, densas e castanhas a pretas; asa castanha na base e castanho-clara no $1 / 3$ apical; pterostigma castanho, da mesma cor e contíguo com a célula r1; fêmur posterior fortemente dilatado no meio, com a face ventral conspicuamente plana; tíbia posterior achatada ânteroposteriormente, levemente ondulada, com a face ventral em forma de quilha, uma cerda D pré-apical curta; lobo hipandrial direito pouco mais longo que a base do hipândrio, largo com ápice arredondado; surstilo direito longo com ápice bífido, divergindo em ângulo maior que $90^{\circ}$.

Holótipo macho. Dimensões, em mm: corpo 5,0; asa 4,7. Flagelo oval-alongado, duas vezes mais longo que largo, mais longo que o escapo e o pedicelo juntos.

Tórax preto, exceto calo pós-alar ligeiramente mais pálido; dorso do escuto, pronoto e escutelo brilhantes, pruinosidade restrita à notopleura, disco pré-escutelar e margens do pronoto e escutelo; pleuras pruinosas, exceto anepisterno e catepisterno com grande área central brilhante. Escuto com cerdas pretas densas, cerdas do disco pré-escutelar duas vezes mais longas que as anteriores; acr e dc multisseriadas, acr com 10 ou mais séries; uma plp curta e delgada no proepímero; $2 \mathrm{npl}$. Escutelo com 4 pares de cerdas, sendo um par apical quase paralelo, longo e forte e 3 cerdas laterais longas, a lateral externa mais longa que as duas laterais internas.

Asa (fig. 64) castanha na base e castanho-pálida no $1 / 3$ apical; pterostigma castanho, da mesma cor e contíguo com a célula r1; célula costal ligeiramente mais larga que a r1.

Pernas com cerdas de revestimento castanhas, esparsas. Perna anterior e média castanho-escuras, exceto o ápice da tíbia posterior e os dois primeiros tarsômeros de todas as pernas amarelos. Fêmur posterior fortemente dilatado, 4 vezes mais longo que largo, com face ventral larga e aplainada para o encaixe da tíbia. Tíbia posterior achatada ântero-posteriormente, face anterior levemente ondulada na metade apical, face ventral em forma de quilha. Cerdas destacadas: tíbia anterior com $1 \mathrm{~A}$ e $1 \mathrm{P}$ pré-apicais curtas, não alcançando a metade do primeiro tarsômero. Tíbia média com 5 cerdas $\mathrm{AD}$, decrescendo em robustez e comprimento em direção ao ápice; $1 \mathrm{AV}$ pré-apical curta e $1 \mathrm{~V}$ pré-apical longa, alcançando o ápice do primeiro tarsômero. Primeiro tarsômero médio com cerdas dorsais muito longas, $1 \mathrm{PV}$ sub-basal mais longa que o comprimento do tarsômero. Trocanter posterior com um espinho $\mathrm{V}$ robusto. Fêmur posterior com uma cerda $\mathrm{AD}$ no $1 / 4$ apical, robusta; $1 \mathrm{AD}$ subapical delgada; 1A mediana e 1A na metade apical; série AV com aproximadamente 10 cerdas espiniformes; face V com 5 cerdas espiniformes, na metade basal do fêmur e 10 espinhos curtos, na metade apical, reduzindo de tamanho, desalinhados e deslocados para a face AV apicalmente; face PV com 5 cerdas espiniformes nos $2 / 3$ apicais. Tíbia posterior com uma cerda $\mathrm{D}$ pré-apical curta.

Abdômen preto, brilhante, com cerdas densas e pretas; duas vezes o comprimento do tórax; $\operatorname{Tg} 1$ e Tg8 com pruinosidade castanha. Terminália (figs. 18-22): lobo hipandrial direito pouco mais longo que a base do hipândrio, largo com ápice arredondado; surstilo direito longo com ápice bífido, divergindo em ângulo maior que $90^{\circ}$, com protuberâncias na face interna e dorsal; esclerito baciliforme com um processo delgado, horizontal, abaixo dos cercos.

Fêmea desconhecida. 

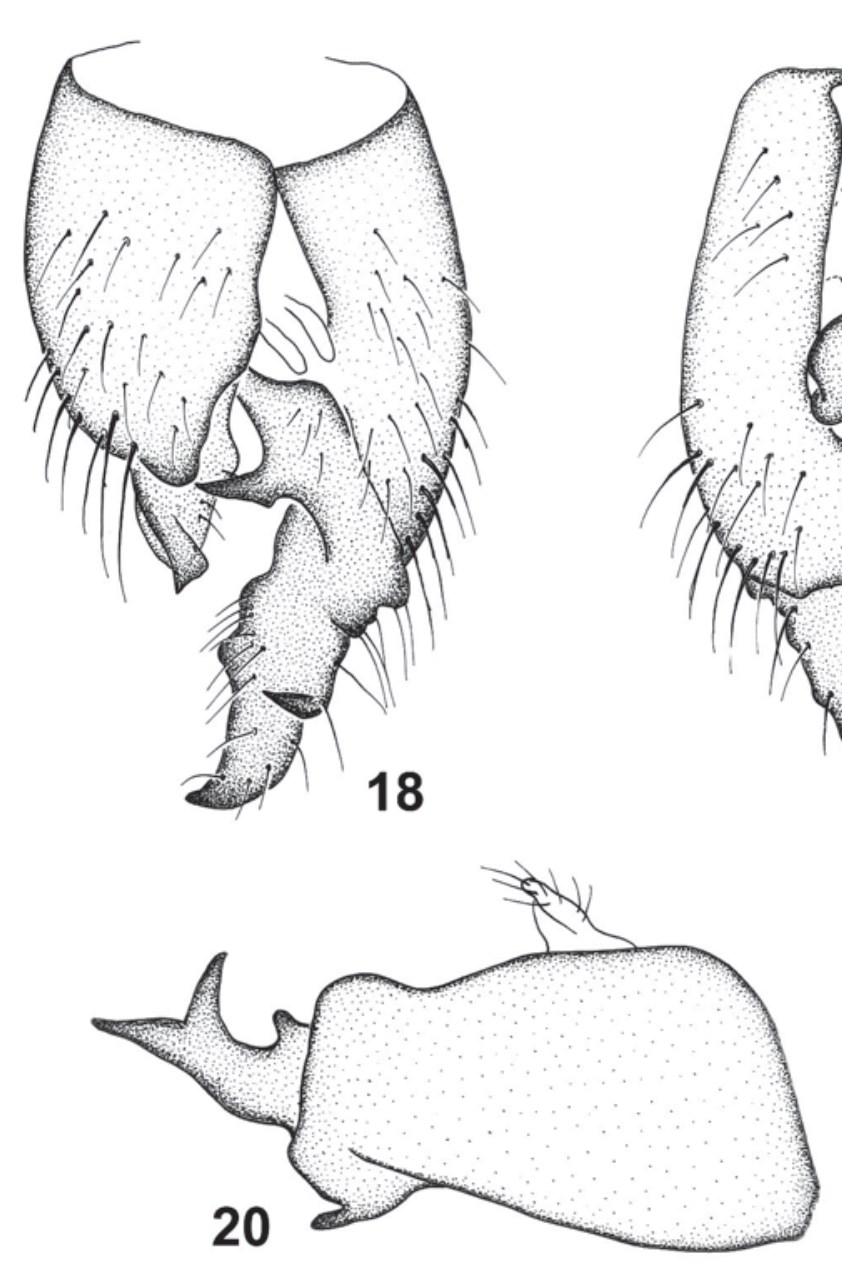
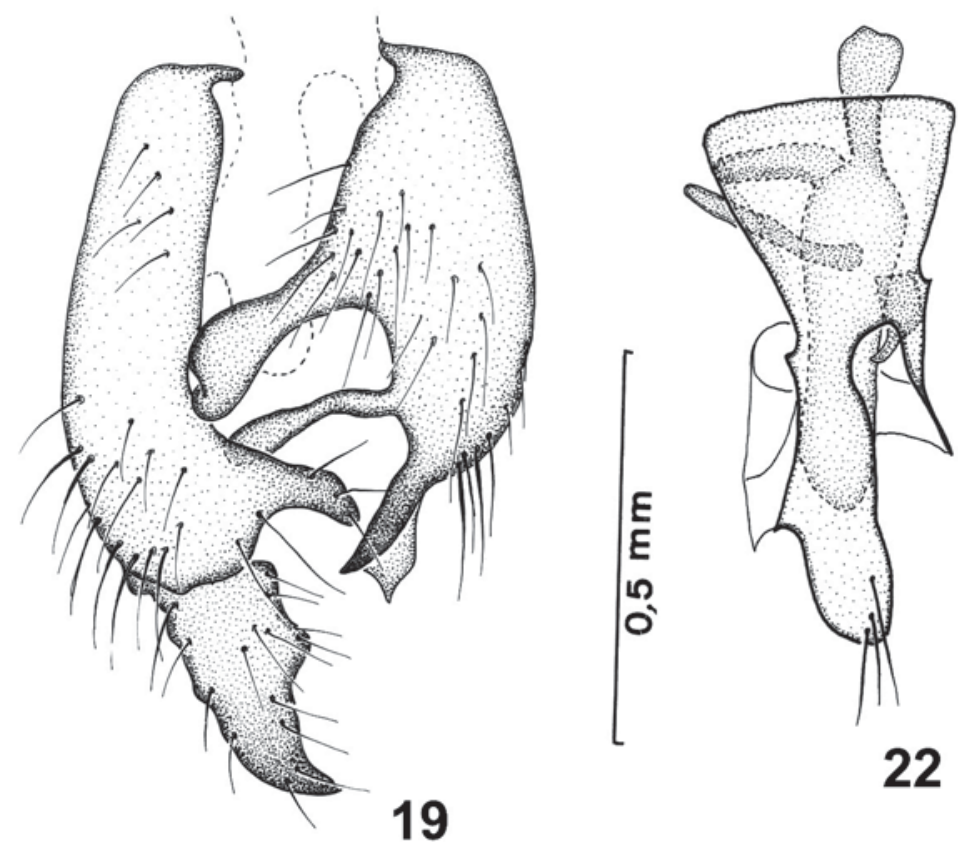

22

Figs. 18-22. E. makauriensis Smith, 1963, o: 18, 19, epândrio, vista dorsal e ventral; 20, 21, lamela epandrial direita e esquerda; 22, hipândrio, vista ventral. Todas as figuras na mesma escala.

Material-tipo. Holótipo $\sigma$, GUIANA, Makauria: 22.IX.1937, Richards \& Smarti (BMNH) (examinado) (asa direita e terminália montadas entre lâminas, colada em papel resistente e afixado ao alfinete do espécime; perna posterior perdida).

Material adicional. BRASIL, Amazonas: Manaus (Reserva Ducke), హ, 29.XI.1989 (INPA); హ゙, 20.VII.1988 (INPA); \%, 17.XI.1988, J.A.Rafael \& Socorro Rosa col. (em flor de Miconia nervosa) (INPA); Querari, $15^{\prime} \mathrm{N}-69^{\circ} 61^{\prime} \mathrm{W}, \sigma^{\prime \prime}$, 8.IV-15.V.1993, João Vidal col. (INPA); Manaus (BR 174, Km 72, Faz. Dimona), 2 o, 11-14.X.1993, F. F. Xavier col. (varredura) (INPA); Pará: Belém, O', 16.VIII.1962, K. Lenko col. (MZSP); Mocambo, హ, 2.IX.1969, T. Pimentel col. (MPEG); Serraria, ơ, 28.VII.1966, T. Pimentel col. (MPEG); Mato Grosso: Chapada dos Guimarães, ơ, 22-30.XI.1983, Bindá col. (INPA); BOLÍVIA, Pando: Porvenir (30 Km SW de Cobija), ơ, 5-9.VII.1979, M. Cooper col. (BMNH).

Distribuição: Guiana, Brasil (Amazonas, Pará, Mato Grosso), Bolívia (Pando).

\section{Euhybus niger sp. nov.}

(Figs. 23-30, 65)

Diagnose. Escuto brilhante dorsalmente, com cerdas curtas e pretas; asa castanha na base, castanhoclara no 1/3 apical; pterostigma castanho, da mesma cor da célula r1; fêmur posterior com face ventral aplainada e larga, levemente côncavo no 1/4 apical; tíbia posterior achatada ântero-posteriormente, face anterior ligeiramente ondulada, face ventral em quilha, sem cerdas destacadas; surstilo direito longo com superfície interna côncava, ápice largo, com 3 pontas curtas; esclerito baciliforme direito com uma projeção sub-basal delgada, vertical.

Holótipo macho. Dimensões, em mm: corpo 4,8; asa 4,4. Flagelo coniforme, 4 vezes mais longo que largo, 1,5 vezes mais longo que o escapo e o pedicelo juntos.

Tórax preto; escuto brilhante no dorso, com pruinosidade castanha restrita à notopleura, disco préescutelar e escutelo. Escuto com cerdas curtas e pretas; acr com 6 séries; 2 npl; cerdas do disco pré-escutelar 3 vezes mais longas que as anteriores. Escutelo com 5 pares de cerdas, sendo um par apical longo, forte e convergente; um par subapical delgado, curto, cerca de $1 / 4$ do comprimento do apical; um par lateral interno, forte, $2 / 3$ do comprimento do apical, e mais 2 pares laterais externos cerca de metade do comprimento do par apical e pouco mais delgado que este.

Asa (fig. 65) com base castanha, castanho-clara no 1/3 apical; pterostigma castanho, da mesma cor da célula r1; margem da célula costal ligeiramente convexa na base. 

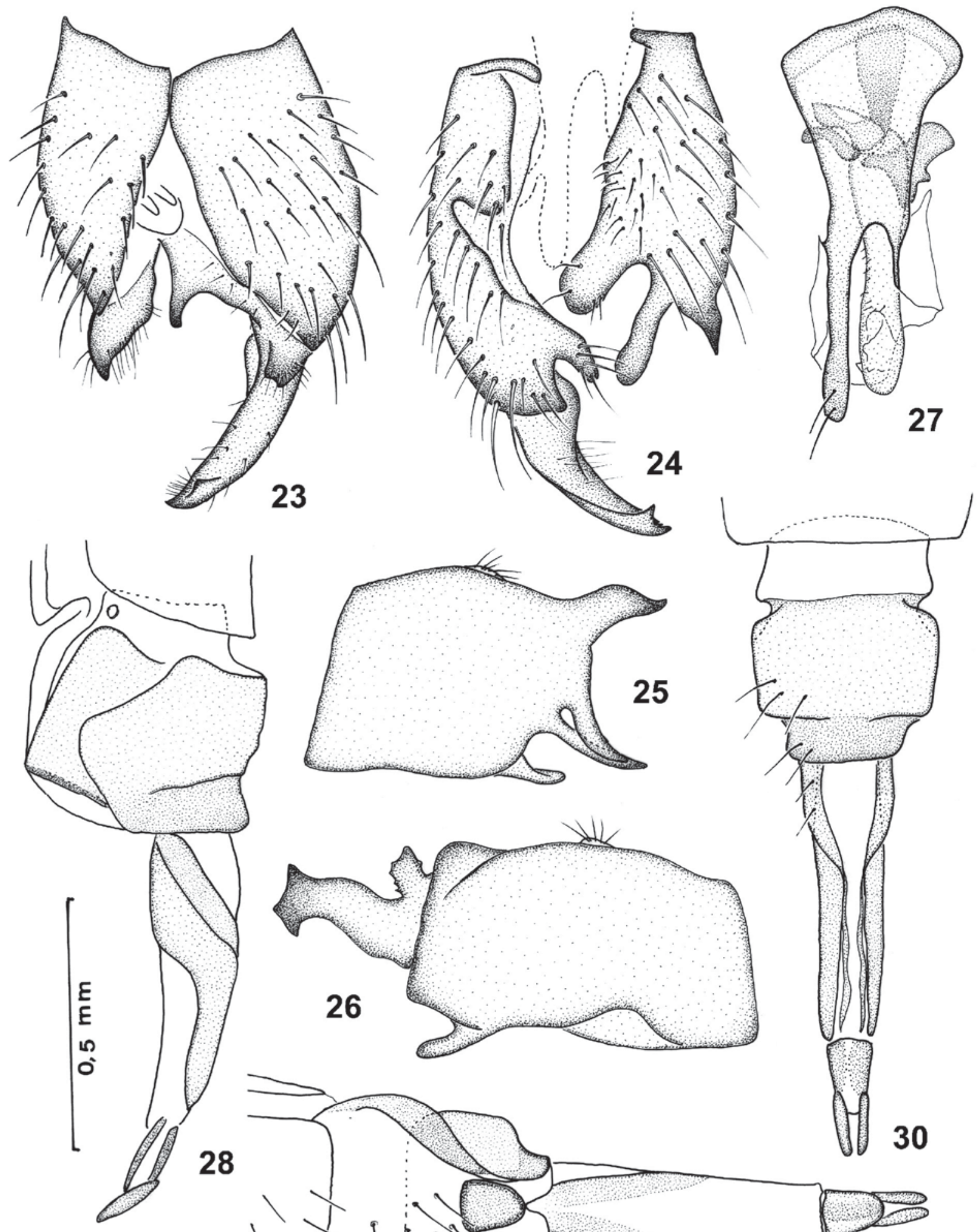

Figs. 23-30. E. niger sp. nov. Parátipo ơ: 23, 24, epândrio, vista dorsal e ventral; 25, 26, lamela epandrial esquerda e direita; 27, hipândrio, vista ventral. Parátipo $\subsetneq$ : 28 , ovipositor, vista lateral; 29 , ventral; 30, dorsal. Todas as figuras na mesma escala. 
Pernas com cerdas de revestimento esparsas, castanhas. Todas as pernas castanhas, exceto as tíbias anterior e média e as extremidades da tíbia posterior, castanho-claras; primeiro e segundo tarsômeros de todos os tarsos amarelos. Fêmur posterior espinhoso, com a face ventral larga e aplainada, conspicuamente dilatado no meio, aproximadamente 5,7 vezes mais longo que largo. Tíbia posterior levemente achatada ânteroposteriormente, face anterior ligeiramente ondulada, face ventral em forma de quilha. Cerdas destacadas: tíbia anterior com 1A curta e 1P longa, alcançando a metade do primeiro tarsômero, pré-apicais. Tíbia média com 3 cerdas AD fracamente destacadas na metade basal, a cerda mais basal 1,5 vezes mais longa que as demais, uma cerda $\mathrm{V}$ apical longa, alcançando o ápice do primeiro tarsômero. Primeiro tarsômero médio com uma cerda PV sub-basal longa, alcançando o ápice do mesmo. Trocanter posterior com um espinho $\mathrm{V}$ curto. Fêmur posterior com uma cerda $\mathrm{AD}$ no 1/4 apical; 3A (uma mediana, uma no $1 / 4$ apical e uma pré-apical); $3 \mathrm{AV}$ espiniformes, na metade apical; face ventral com duas séries de cerdas: uma externa, com 6 espinhos basais longos e 5 distais curtos, e uma interna, com 7 espinhos na metade basal e 6 espinhos pré-apicais curtos com bases protuberantes; série PV com 9 espinhos nos 2/3 apicais e um espinho próximo da base. Tíbia posterior sem cerdas destacadas.

Abdômen 2,8 vezes mais longo que o tórax, preto, brilhante, com reflexo azul metálico. Tg1 e Tg8 com pruinosidade castanha; $\mathrm{Tg} 1$ e $\mathrm{Tg} 2$ com cerdas laterais castanhas. Terminália (figs. 23-27): surstilo direito longo com superfície interna côncava, ápice largo, com 3 pontas curtas; esclerito baciliforme direito com uma projeção subbasal delgada, vertical, quase reta, abaixo dos cercos.

Fêmea. Semelhante ao macho, exceto: flagelo 5 vezes mais longo que largo, 3 vezes mais longo que o escapo e o pedicelo juntos. Tíbia média com 3 cerdas D destacadas perto da base. Trocanter posterior sem espinhos. Fêmur posterior mais delgado, face ventral normal, 6 vezes mais longo que largo, com uma cerda $\mathrm{A}$ no 1/4 apical, 5AV na metade apical, 9-10 espinhos V na metade apical e série PV com 4 cerdas próximas do ápice. Ovipositor como nas figuras 28-30.

Material-tipo. Holótipo ơ, EQUADOR, Napo: Tena, 1119.IV.1976, M. Cooper, BM, 1995E - 90 (BMNH) (em bom estado, não dissecado). Parátipos. EQUADOR, Napo: Tena, 2 \%", 3 †, 11-19.IV.1976, M. Cooper col., BM, 1995E - 90 (BMNH); o, \& (INPA); COLÔMBIA, Puntamayo: Vila Garzon, 2 o', \&, 1626.VII.1978, M. Cooper col., BM 1995E-90 (BMNH); ơ \& (INPA); Caqueta: Yuruyacu (70Km SW Florencia), ơ, 15.I.1979, M. Cooper col., BM 1995E-90 (BMNH).

Distribuição. Equador (Napo) e Colômbia (Puntamayo, Caqueta).

Discussão. E. niger sp. nov. assemelha-se superficialmente, nos aspectos da terminália masculina, às espécies com surstilo direito alongado, $E$. makauriensis, E. reduncus sp. nov. e E. tomentosus sp. nov. Entretanto, o surstilo de E. niger sp. nov. tem a superfície interna côncava e o ápice largo, com três pontas, diferindo das espécies citadas. Difere, ainda, de E. makauriensis pelo lobo hipandrial direito longo e estreito, de E. reduncus sp. nov. pelo surstilo esquerdo trífido e esclerito baciliforme direito com projeção subbasal delgada, vertical, e de E. tomentosus sp. nov. pelo escuto sem pruinosidade, brilhante dorsalmente.

Etimologia. O nome específico se refere à coloração da espécie.

\section{Euhybus novoaripuanensis sp. nov.}

(Figs. 31-38, 66 )

Diagnose. Escuto brilhante dorsalmente, com cerdas curtas, pretas; asa castanha, ligeiramente mais clara no 1/4 apical; pterostigma castanho; tíbia posterior achatada ântero-posteriormente, face ventral em forma de quilha, com a face anterior ligeiramente ondulada, uma cerda $\mathrm{D}$ pré-apical curta; lobo hipandrial direito alargado; surstilo direito robusto em vista dorsal e ventral, sem protuberâncias na face ventral, face dorsal com uma projeção curta no meio e um tubérculo basal; esclerito baciliforme com uma projeção delgada, horizontal com ápice curvado para baixo.

Holótipo macho. Dimensões, em mm: corpo 4,8; asa 4,6. Flagelo coniforme, 3 vezes mais longo que largo, tão longo quanto o escapo e o pedicelo juntos.

Tórax preto; escuto brilhante no dorso, com pruinosidade castanha restrita à notopleura, disco préescutelar e escutelo; pleuras pruinosas, exceto anepisterno e catepisterno com a porção central brilhante. Escuto com cerdas pretas, numerosas, curtas; acr com 810 filas; $2 \mathrm{npl}$; cerdas do disco pré-escutelar aproximadamente 1,5 vezes o comprimento das anteriores. Escutelo com 5 pares de cerdas longas e robustas, o par apical paralelo e convergente, ligeiramente mais longo que os demais.

Asa (fig. 66) castanha, ligeiramente mais clara no 1/4 apical; pterostigma castanho; margem de célula costal ligeiramente convexa na base.

Pernas com cerdas de revestimento castanhoescuras. Perna anterior e média castanhas e perna posterior castanho-escura, exceto as extremidades da tíbia posterior, primeiro e segundo tarsômeros de todas as pernas, amarelos. Fêmur posterior fortemente dilatado, 4 vezes mais longo que largo, face $V$ aplainada com leve concavidade na porção mediana. Tíbia posterior achatada ântero-posteriormente, face ventral afilada em forma de quilha, face anterior ligeiramente ondulada. Cerdas destacadas: tíbia anterior com 1A curta e 1P alcançando a metade do primeiro tarsômero, pré-apicais. Tíbia média com $5 \mathrm{AD}$, a basal distintamente mais longa que as demais; $1 \mathrm{~V}$ pré-apical longa, alcançando o ápice do primeiro tarsômero. Primeiro tarsômero médio com duas cerdas D longas e robustas (uma basal e uma apical), uma cerda $\mathrm{V}$ sub-basal longa, ultrapassando o ápice do mesmo. Trocanter posterior com um espinho V. Fêmur posterior com uma cerda $\mathrm{AD}$ no $1 / 5$ apical e $3 \mathrm{~A}$ (uma pré-apical, uma no 1/4 apical e uma mediana); série AV com 13 cerdas espiniformes; série V com 18 espinhos curtos e série PV com 10 espinhos pouco mais longos que os ventrais, com bases protuberantes. Tíbia posterior com uma cerda D pré-apical curta. Tarso posterior sem espinhos.

Abdômen 2,8 vezes mais longo que o tórax, com cerdas pretas. Tg8 com pruinosidade castanha. Terminália (figs. 31-35): lobo hipandrial direito alargado; surstilo 

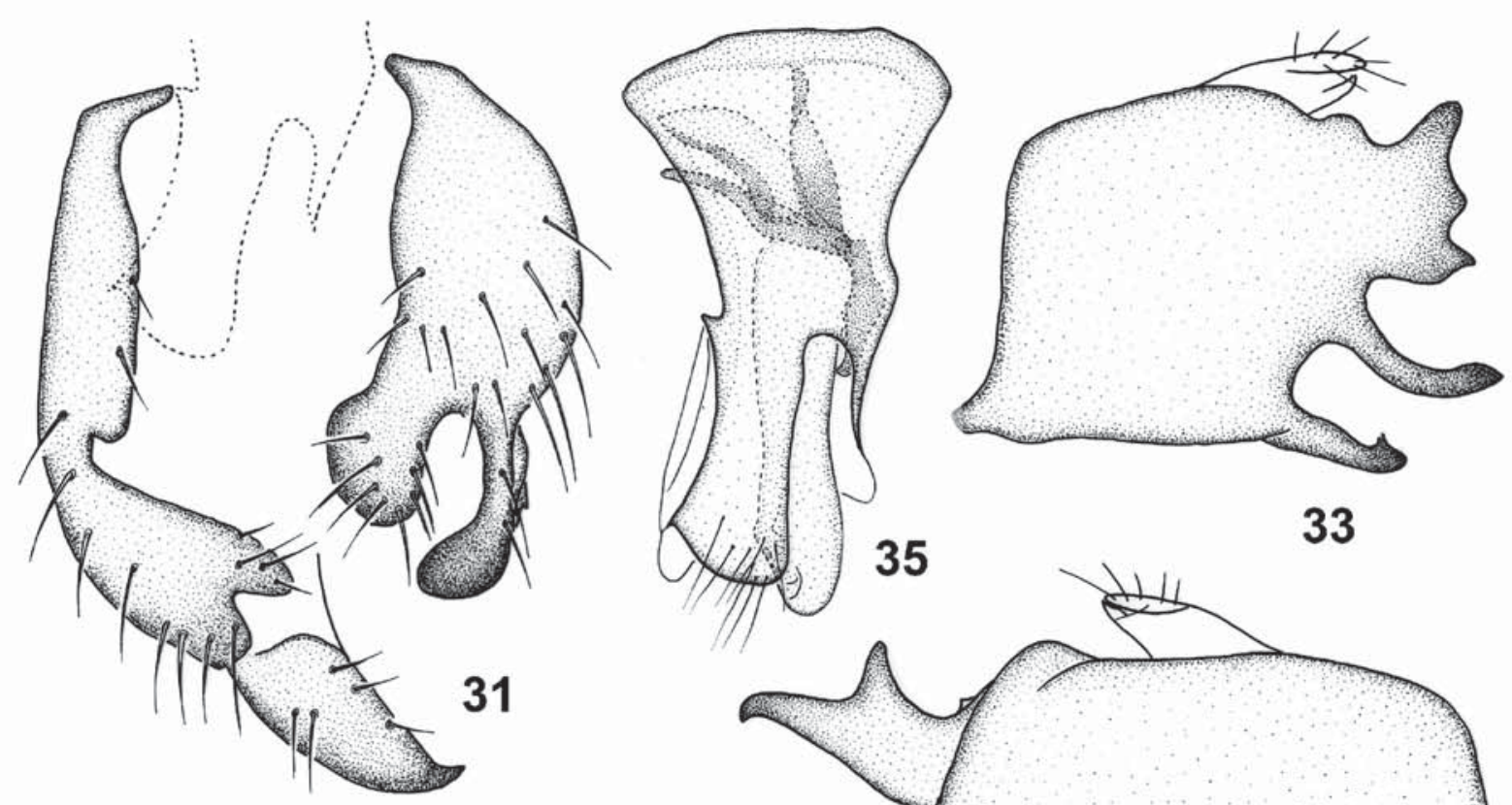

33

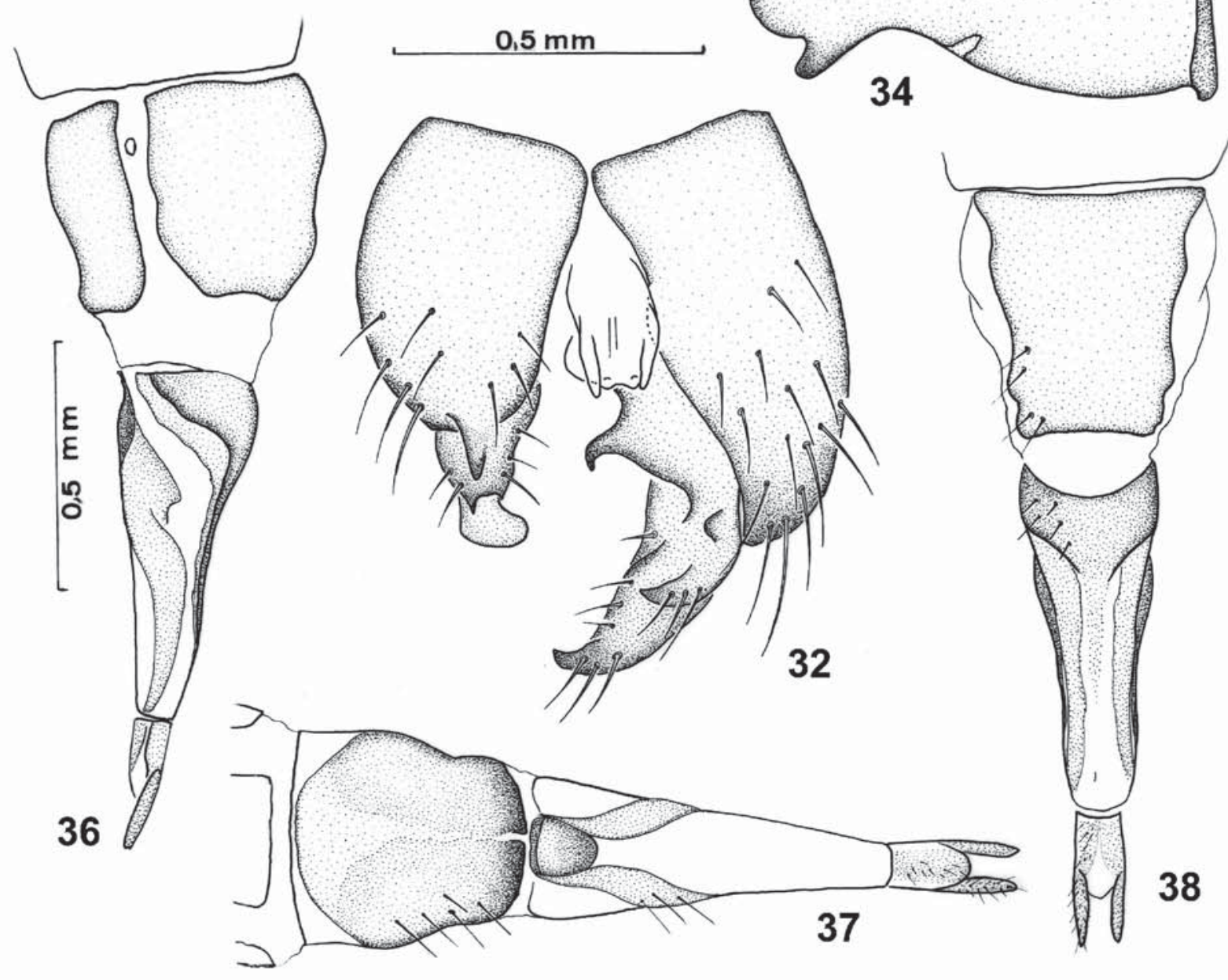

Figs. 31-38. E. novoaripuanensis sp. nov. Parátipo o': 31, 32, epândrio, vista ventral e dorsal; 33, 34, lamela epandrial esquerda e direita; 35, hipândrio, vista ventral. Parátipo \&: 36, ovipositor, vista lateral; 37, ventral; 38, dorsal. Figs. 31-35; 36-38 na mesma escala. 
direito robusto em vista dorsal e ventral, sem protuberâncias na face ventral, face dorsal com uma projeção curta no meio e um tubérculo basal; esclerito baciliforme com uma projeção delgada, horizontal, com ápice curvado para baixo.

Fêmea. Semelhante ao macho, exceto: flagelo 4,5 vezes mais longo que largo, duas vezes mais longo que o escapo e o pedicelo juntos. Escutelo com 5 pares de cerdas longas e robustas, sendo o par apical paralelo, 1,5 vezes mais longo que os demais os quais são convergentes. Fêmur posterior delgado, face ventral normal, com uma cerda $\mathrm{AD}$ próxima do ápice e $2 \mathrm{~A}$ no $1 / 3$ apical; série AV com 8 cerdas espiniformes, duas das quais próximas da base e 6 nos 2/3 apicais, diminuindo em tamanho e espessura em direção ao ápice do fêmur; série V com 12 espinhos curtos nos 2/3 apicais; série PV com 5 espinhos alongados, na metade apical. Ovipositor como nas figuras $36-38$.

Material-tipo. Holótipo ơ, BRASIL, Amazonas: Novo Aripuanã, $06^{\circ} 15^{\prime} 53^{\prime \prime} \mathrm{S}, 60^{\circ} 07^{\prime} 08^{\prime \prime} \mathrm{W}$, Reserva SOKA, 28.IV5.V.1999, Ale-Rocha, R. \& Vidal, J. F. cols., varredura, mata (INPA) (asa danificada; terminália dissecada). Parátipos: 2 \&, mesmos dados do holótipo (INPA).

Distribuição. Brasil (Amazonas).

Discussão. Espécie semelhante a E. makauriensis pela forma do surstilo direito e hipândrio, porém, difere pela margem distal do lobo hipandrial arredondada, processo do esclerito baciliforme horizontal, com ápice curvado para baixo e formato do surstilo esquerdo.

Etimologia. O nome específico refere-se à localidade-tipo.

\section{Euhybus piceus (Wiedemann, 1830) \\ (Figs. 39-46, 67)}

Hybos piceus Wiedemann, 1830:647; Bezzi, 1909:305 (chave); BECKER, 1919:171.

Hybos integer Walker, 1852:205 (sinonimizado por SмITH, 1964). Lactistomyia piceia; Melander, 1927:36 (chave); Smith, 1962:217. Euhybus piceus; SмIтн, 1964:50, figs. 1, 2 (redescrição, designação do lectótipo).

Diagnose. Escuto pruinoso dorsalmente, com cerdas castanho-claras a amarelas, longas e densas; asa castanha, ligeiramente castanho-clara na metade apical, pterostigma castanho; tíbia posterior tubular, sem cerdas destacadas; surstilo esquerdo com dois prolongamentos divergentes; epândrio com numerosas cerdas longas na porção mediana da margem ventral.

Lectótipo fêmea. Dimensões, em mm: corpo 4,5; asa 3,6. Cabeça perdida. Tórax castanho-escuro; escuto e escutelo com densa pruinosidade castanha dorsalmente, exceto a margem anterior, entre os lobos pós-pronotais, brilhante; mesopleura brilhante na maior parte, com pruinosidade somente nas margens dos escleritos e porção superior do anepímero, laterotergito com pruinosidade inconspícua, meron e porção inferior do catepisterno com pruinosidade grosseira (tomentum). Escuto com cerdas longas, densas, castanho-claras a amarelas; séries dc e acr multisseriadas, muito aproximadas, indistintamente separadas, pelo menos duas vezes mais longas no disco pré-escutelar; acr com 6-8 séries; notopleura cerdosa; propleura com cerda marginal delgada; 3 npl longas. Escutelo com 4 pares de cerdas, sendo um par apical longo, divergente e mais 3 cerdas delgadas de cada lado, cerca de metade do comprimento do par apical.

Asa castanha (fig. 67), ligeiramente castanho-clara na metade apical, pterostigma castanho; célula costal ligeiramente mais larga que a r1, com a margem levemente arredondada.

Pernas com cerdas de revestimento delgadas e pálidas. Coxas, fêmur e tíbia posterior e os três tarsômeros distais de todas as pernas castanhos; fêmur anterior e médio, tíbia posterior e média e os dois tarsômeros basais de todas as pernas castanho-claros a amarelos. Fêmur posterior dilatado, quase 6 vezes mais longo que largo. Tíbia posterior tubular. Cerdas destacadas: tíbia anterior com 1A pré-apical curta. Primeiro tarsômero anterior e médio com $1 \mathrm{PV}$ e $1 \mathrm{AV}$ sub-basais longas. Tíbia média com $4 \mathrm{AD}$ mais longas que a cerda ventral, diminuindo em comprimento e espessura em direção ao ápice da tíbia; $1 \mathrm{~V}$ apical longa, cerca de $2 / 3$ do comprimento do primeiro tarsômero. Trocanter posterior sem espinho. Fêmur posterior: face $\mathrm{AV}$ com 7 cerdas espiniformes, uma cerda AD no 1/5 apical, 1A no 1/4 apical e 1A mediana; série PV com cerdas espiniformes curtas na metade apical do fêmur; série $\mathrm{V}$ com espinhos inseridos em bases protuberantes. Tíbia posterior sem cerdas destacadas.

Abdômen castanho-escuro, brilhante, com cerdas delgadas castanho-claras, as cerdas dorsais mais escuras, curtas e esparsas. Ovipositor como nas figuras 44-46.

Macho descrito por Sмiтн (1964), que incluiu uma figura da terminália. Acrescenta-se os caracteres seguintes: fêmur posterior mais robusto que na fêmea, 4,6 vezes mais longo que largo. Terminália (figs. 39-43): surstilo esquerdo delgado e bífido distalmente, com dois prolongamentos digitiformes e divergentes; epândrio com numerosas cerdas longas e delgadas, na porção mediana da margem ventral.

Material-tipo. Euhybus piceus. Lectótipo \&, BRASIL, Minas Gerais: S. João d. Rey, Sello col. (ZMHU) (o espécime encontra-se parcialmente destruído). Euhybus integer. Holótipo §', BRASIL, Euhybus integer (BMNH) (terminália, tíbia direita, tarso direito e esquerdo perdidos).

Material adicional. BRASIL, Minas Gerais: Arceburgo, o, \&, XII.1946, M.P. Barreto col. (INPA); Sapucai-Mirim (Cidade Azul), ơ, 7.IX.1953 (MZSP); Rio de Janeiro: Nova Friburgo, o, 24.IV.[19]37, S. Lopes col. (INPA); Itatiaia (Maromba), o, , \&, IX.1946, Barreto col. (INPA); Ғ, I.1948, C. d'Andretta col. (MZSP); São Paulo: Serra da Cantareira, Cantareira, $\subsetneq$, VIII.[19]45; đ, XI.1946, S. Lane col. (MZSP); Chapadão, \&, IV.1946, Barreto col. (MZSP); F, VIII.1946 (MZSP); Cajuru (Coqueiros), 2 o, 3 f, II.1947 (INPA); São Paulo (Jaraguá), $\&$, VIII.[19]45, J. Lane col. (MZSP); \&, X.1945 (MZSP); ơ, 14.VIII.1947, E. Rabello col. (MZSP); Salesópolis (Estação Biológica Boracéia), 2 f, IX.1948, Barreto col. (MZSP); Barueri, \&, 15.XII.[19]65, K. Lenko col. (MZSP); Santa Catarina: Nova Teutônia, ơ, 8.VIII.1934 (AMNH); \&, X.1965; 4 đ', VII.1967, F. Plaumann col.; 3 హ, 3 \&, IX.1967; đ, VII.1971; 11 ठ, 4 \&, IX.[19]71; 3 o, \&, X.[19]71 (MZSP); 4 ơ, \&, XI.[19]71 (INPA); Rio Grande do Sul: Canela, 3 đ', 2 \&, I.1984, M. Hoffmann col. (INPA).

Distribuição. Brasil (Minas Gerais, Rio de Janeiro, São Paulo, Santa Catarina, Rio Grande do Sul).

Variação. Alguns espécimes com a célula costal ligeiramente mais estreita que no lectótipo e o fêmur posterior sem cerdas fortes no quarto apical da face 

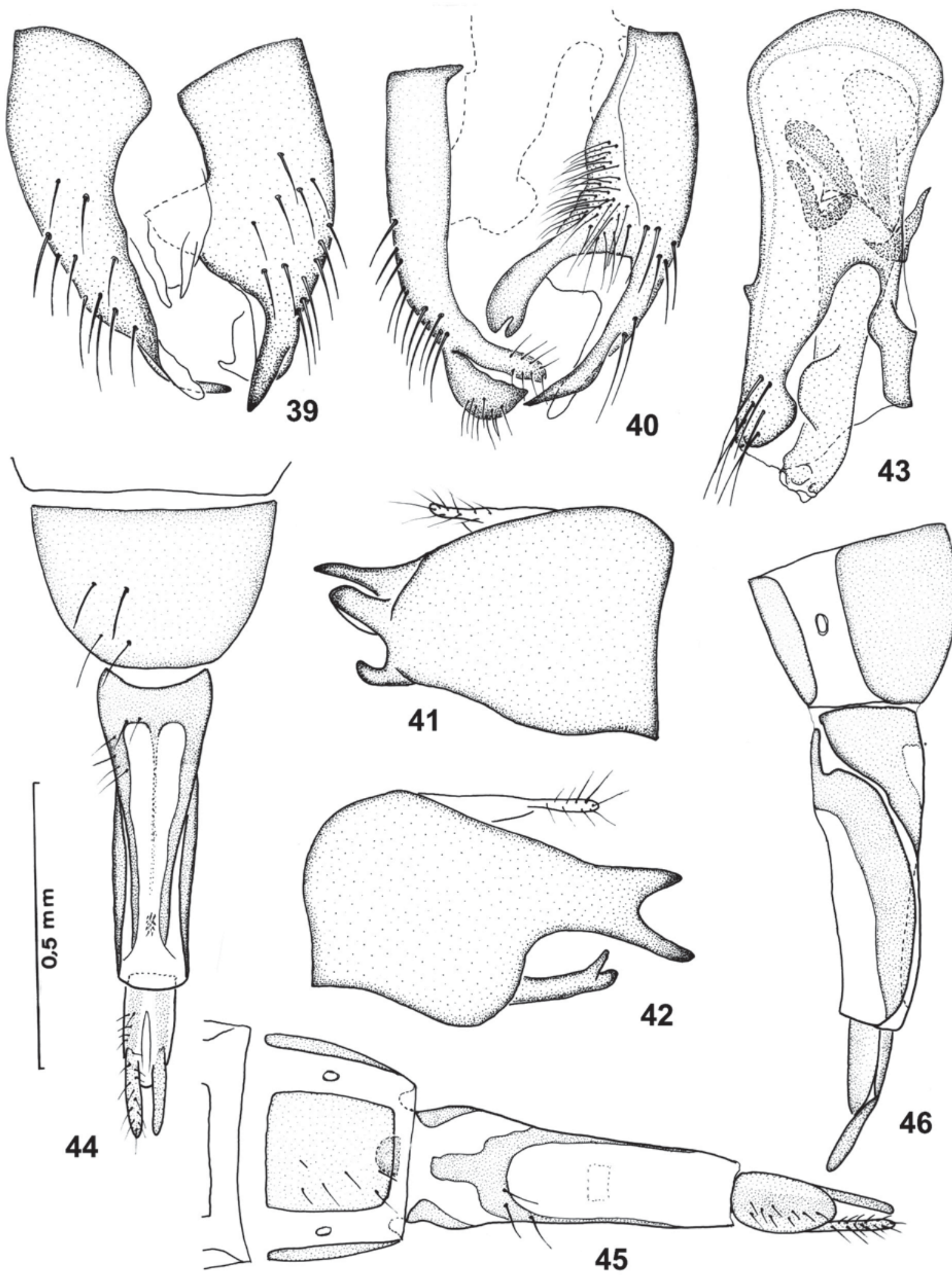

Figs. 39-46. E. piceus (Wiedemann, 1830), ö: 39, 40, epândrio, vista dorsal e ventral; 41, 42, lamela epandrial direita e esquerda; 43, hipândrio, vista ventral. §: 44, ovipositor, vista dorsal; 45, ventral; 46, lateral. Todas as figuras na mesma escala. 
anterior; a cor varia do castanho ao preto, exceto a perna média e posterior castanhas.

\section{Euhybus reduncus sp. nov.}

(Figs. 47-53, 68)

Diagnose. Escuto com cerdas delgadas, densas, castanhas e curtas, brilhante dorsalmente; dorso do tórax acuminado; asa com metade basal castanho-clara, o restante hialino; pterostigma sub-hialino; tíbia posterior reta, tubular, mas com uma quilha ventral suave, sem cerdas destacadas; surstilo direito longo e delgado, dobrado no meio para dentro, em ângulo quase reto.

Holótipo macho. Dimensões, em mm: corpo 5,2; asa 4,2 . Flagelo oval, duas vezes mais longo que largo, pouco mais longo que o escapo e o pedicelo combinados.

Tórax com escuto castanho-escuro, lóbulo póspronotal e pleuras castanhos; escuto brilhante no dorso, com pruinosidade restrita à notopleura e disco préescutelar; uma grande área brilhante, sem pruinosidade, abrangendo o anepisterno, anepímero e catepisterno. Dorso do escuto alto e acuminado, piramidal, com cerdas delgadas, densas e castanhas, curtas anteriormente e cerca de duas vezes mais longas no disco pré-escutelar; acr com 8-10 fileiras; notopleura cerdosa com 2 npl longas e delgadas. Escutelo cerdoso, com 9 pares de cerdas: um par apical e um pré-apical longos, e 7 cerdas de cada lado sendo 4 mais internas medindo cerca de metade do comprimento do par apical e 3 cerdas mais externas, curtas e delgadas.

Asa (fig. 68) com metade basal castanho-clara e o restante hialino; pterostigma sub-hialino; célula costal tão larga quanto a r1.

Pernas com cerdas de revestimento castanhas. Todas as pernas castanhas, exceto a tíbia média, base da tíbia posterior e os dois primeiros tarsômeros de todas as pernas amarelos. Fêmur posterior 5 vezes mais longo que largo. Tíbia posterior reta, tubular mas com quilha afiada na face ventral, face póstero-ventral ligeiramente escavada e uma quilha mais suave na face posterior que termina em uma pequena projeção delgada no ápice da tíbia. Cerdas destacadas: tíbia anterior com 1A e 1P préapicais alongadas, alcançando a metade do primeiro tarsômero e uma cerda D preapical curta. Tíbia média com 4 cerdas AD longas, a basal 1,5 vezes mais longa que as demais e $1 \mathrm{~V}$ apical alcançando o ápice do primeiro tarsômero. Primeiro tarsômero médio com 2PV sub-basais, a basal medindo cerca de $1 / 4$ do comprimento da cerda seguinte, esta é longa, ultrapassando o ápice do primeiro tarsômero. Primeiro tarsômero anterior somente com as cerdas apicais destacadas. Trocanter posterior com 2 espinhos ventrais fortes. Fêmur posterior com uma cerda AD no 1/4 apical; 4A (uma no $1 / 4$ basal, uma mediana, uma no $1 / 3$ apical e uma pré-apical); série AV com 10 cerdas espiniformes; série $\mathrm{V}$ com 16 cerdas irregularmente alinhadas, sendo 8 mais apicais reduzidas a espinhos muito curtos e 8 desenvolvidas distribuídas nos $2 / 3$ basais, 4 delas deslocadas para a face $\mathrm{AV}$ na porção média do fêmur e 4 basais, na mesma linha dos espinhos apicais; série PV com 10 cerdas espiniformes com bases protuberantes; $2 \mathrm{P}$ (uma mediana e uma no $1 / 3$ apical). Tíbia posterior sem cerdas destacadas.
Abdômen três vezes mais longo que o tórax; castanho com cerdas castanho-claras longas nos tergitos 1-3, cerdas dorsais inconspícuas; brilhante, sem pruinosidade, exceto o $\mathrm{Tg} 8 \mathrm{com}$ pruinosidade castanha. Terminália (fig. 47-51): surstilo direito longo, delgado, dobrado no meio, para dentro, em ângulo quase reto; hipândrio fortemente estreitado no meio.

Fêmea. Semelhante ao macho, exceto: trocanter posterior sem espinho; fêmur posterior mais delgado com cerdas mais espaçadas e em menor número: $1 \mathrm{~A}$ no $1 / 4$ apical, 9AV mais delgadas que no macho, série $\mathrm{V}$ com 14 espinhos muito curtos ocupando os $2 / 3$ apicais do fêmur, série PV com 5 cerdas espiniformes no 1/3 apical. Ovipositor como nas figuras 52 e 53.

Material-tipo. Holótipo ơ, BRASIL, São Paulo: Cajuru (Coqueiros), II.1947, Barreto col. (MZSP) (em bom estado, não dissecado). Parátipos. Mesmos dados, $\sigma, \subsetneq$ (MZSP); Minas Gerais: Arcerburgo (F. Fortaleza), f, XII.1946, Barreto col. (MZSP); Goiás: Corumbá (F. Monjolinho), ơ, \&, XI.1945, Barreto col. (INPA); 2 \%, $\subsetneq$ (MZSP). Paulo).

Distribuição. Brasil (Goiás, Minas Gerais, São

Discussão. E. reduncus sp. nov. assemelha-se superficialmente, nos aspectos da terminália masculina, às espécies com surstilo direito alongado, $E$. makauriensis, E. niger sp.nov. e E. tomentosus sp. nov. Entretanto, o surstilo direito de E. reduncus sp. nov. é delgado, fortemente curvado ao meio para dentro, em ângulo quase reto, o hipândrio é fortemente estreitado no meio e o pterostigma é muito fraco, sub-hialino, diferindo de todas as espécies citadas.

Etimologia. Latim: reduncus $=$ curvado para trás. $\mathrm{O}$ nome específico se refere ao formato do surstilo.

\section{Euhybus tomentosus sp. nov.}

(Figs. 54-61, 69)

Diagnose. Escuto pruinoso dorsalmente, com cerdas castanhas, delgadas, curtas e densas; asa castanho-clara nos $2 / 3$ basais e o restante hialino, pterostigma castanho; tíbia posterior tubular, falciforme, com uma cerda D pré-apical discretamente destacada; surstilo direito longo, maior que metade do comprimento do epândrio, levemente curvado para dentro; surstilo esquerdo com ápice largo e truncado.

Holótipo macho. Dimensões, em mm: corpo 5,6; asa 4,0 . Flagelo oval, duas vezes mais longo que largo, igual ao escapo e pedicelo combinados.

Tórax preto com lobo pós-pronotal e pleuras castanhas a castanho-claras; escuto pruinoso dorsalmente, com pruinosidade densa, castanhoavermelhada; lobo pós-pronotal brilhante, sem pruinosidade; pleuras com pruinosidade esparsa, com grande área brilhante incluindo parte do anepisterno, catepisterno e anepímero. Escuto com cerdas delgadas, densas, castanhas, cerdas do disco pré-escutelar cerca de 1,5 a 2 vezes o comprimento das anteriores; acr e dc multisseriadas, acr com 10 ou mais séries; notopleura cerdosa com $2 \mathrm{npl}$ longas e fortes. Escutelo com 3 pares de cerdas sendo um par apical longo, divergente e duas cerdas finas de cada lado, que são $1 / 4$ do comprimento do par apical. 


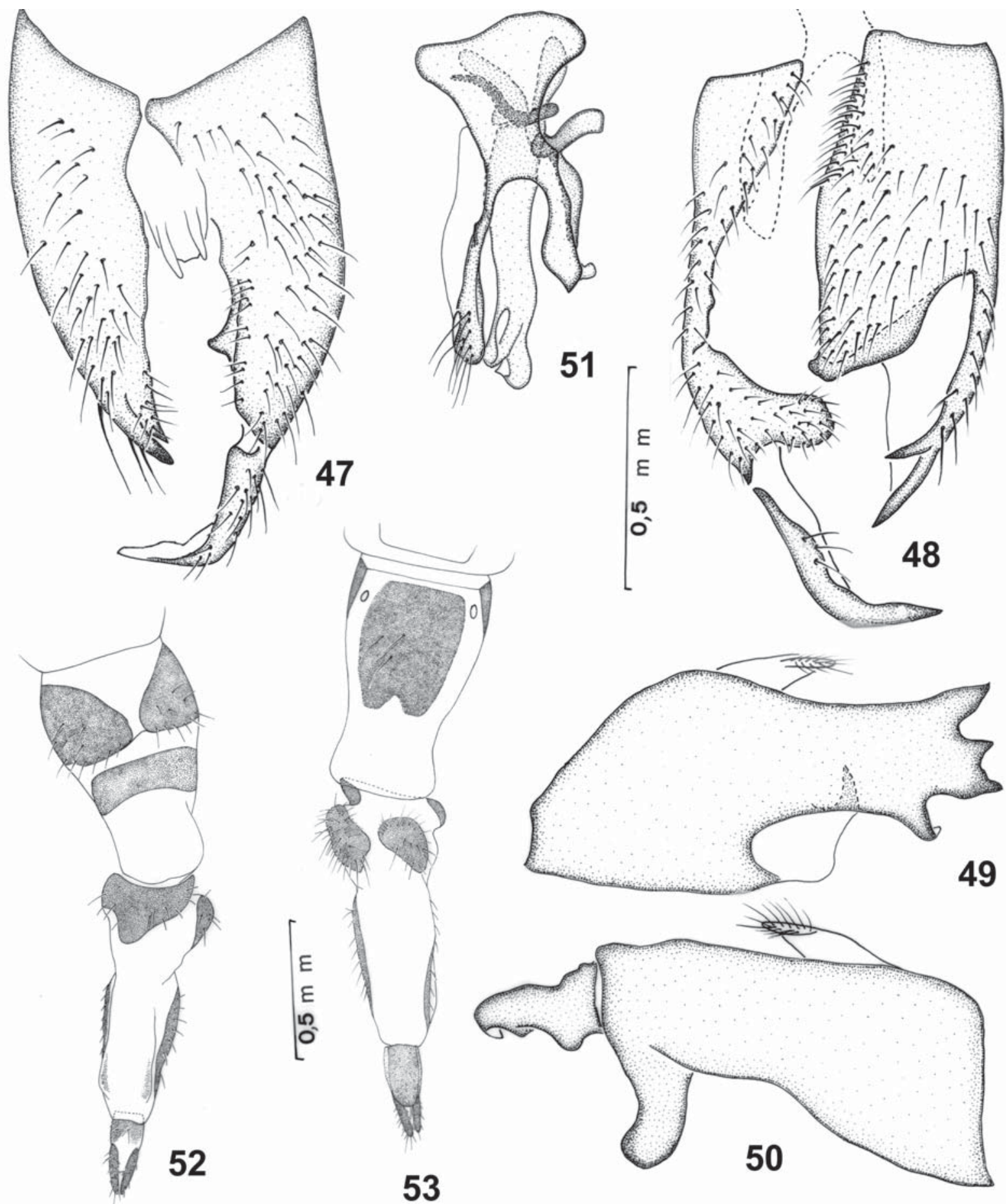

Figs. 47-53. E. reduncus sp. nov. Parátipo ơ: 47, 48, epândrio, vista dorsal e ventral; 49, 50, lamela epandrial esquerda e direita; 51, hipândrio, vista ventral. Parátipo ł: 52, ovipositor, vista dorsal; 53, ventral. Figs. 47-51; 52-53 na mesma escala.

Asa (fig. 69) castanho-clara nos $2 / 3$ basais, o restante hialino, pterostigma castanho; célula costal tão larga quanto a r1, com a margem suavemente côncava, margem costal com cerdas alongadas.

Pernas com cerdas de revestimento amareladas. Todas as coxas e trocanter posterior castanho-escuros; fêmur posterior castanho-escuro com extremidades mais claras; fêmur anterior e médio castanhos com ápices amarelos; tíbia anterior e média amarelas; tíbia posterior castanho-clara; primeiro e segundo tarsômeros amarelos, terceiro ao quinto tarsômeros castanhos. Fêmur posterior 4,5 vezes mais longo que largo. Tíbia posterior tubular, falciforme. Cerdas destacadas: tíbia anterior com 1A, 1D e 1P pré-apicais, curtas, não alcançando a metade do primeiro tarsômero. Tíbia média com 4 cerdas AD nos $2 / 3$ basais, pretas e robustas; $1 \mathrm{~V}$ apical cerca de $2 / 3$ do comprimento do primeiro tarsômero. Primeiro tarsômero médio com 2PV sub-basais, a basal cerca de $1 / 4$ do 


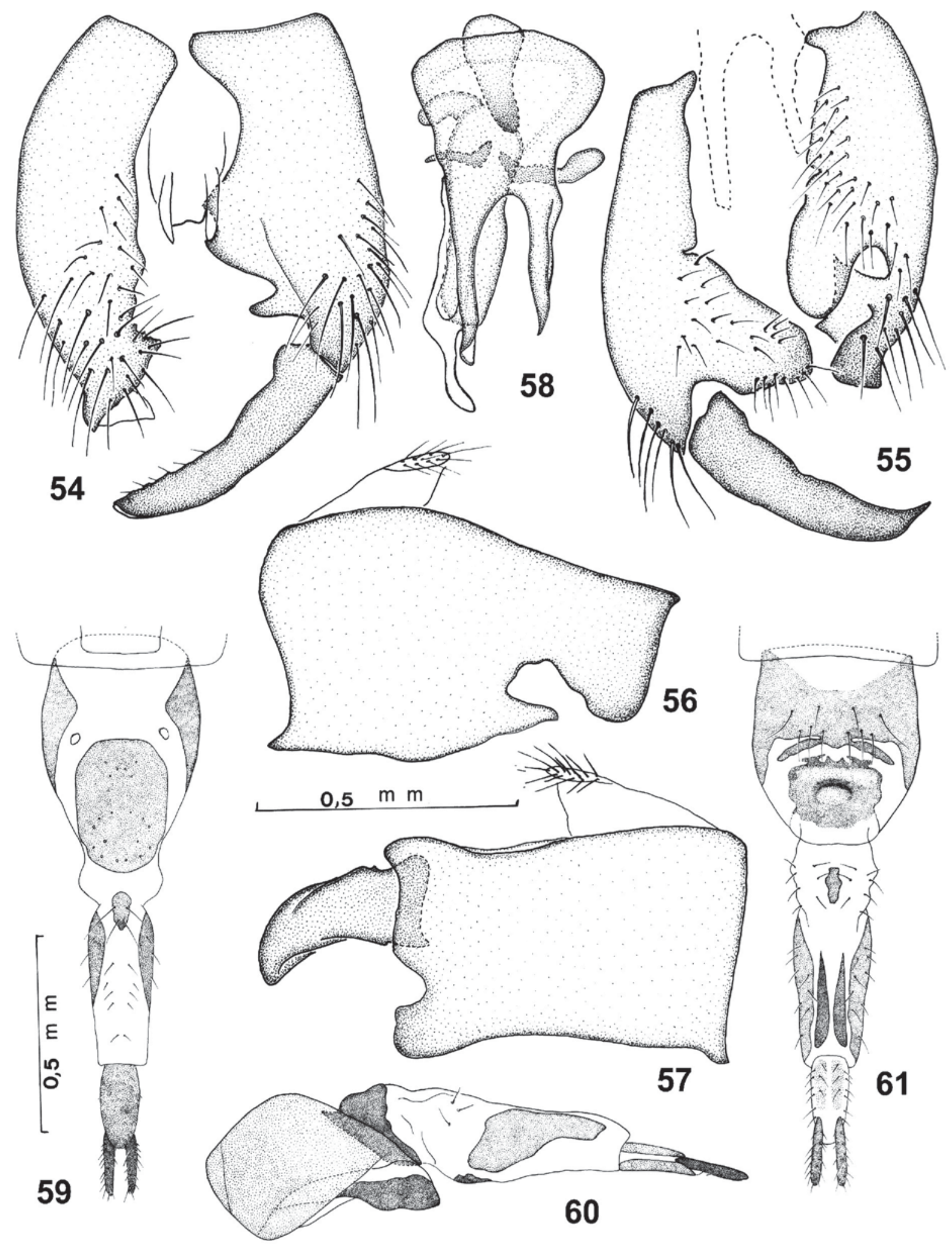

Figs. 54-61. E. tomentosus sp. nov. Parátipo ơ: 54, 55, epândrio, vista dorsal e ventral; 56, 57, lamela epandrial esquerda e direita; 58, hipândrio, vista ventral. Parátipo f: 59, ovipositor, vista ventral; 60, lateral; 61, dorsal. Figs. 54-58; 59-61 na mesma escala.

comprimento da cerda seguinte que é mais longa, ultrapassando o ápice do tarsômero; uma cerda AD mediana $1 \mathrm{AD}$ apical longas. Tíbia posterior e primeiro tarsômero posterior com uma cerda A apical curta discretamente destacada. Fêmur posterior com uma cerda
AD no 1/5 apical; 1 A pré-apical e 1 A no $1 / 3$ apical; série $\mathrm{AV}$ com 12 cerdas alongadas, espiniformes; face $\mathrm{V}$ com 7 cerdas espiniformes alongadas distribuídas nos $2 / 3$ basais e 7 cerdas reduzidas a espinhos curtos, no $1 / 3$ distal e uma fileira adicional de 4 cerdas espiniformes formando 


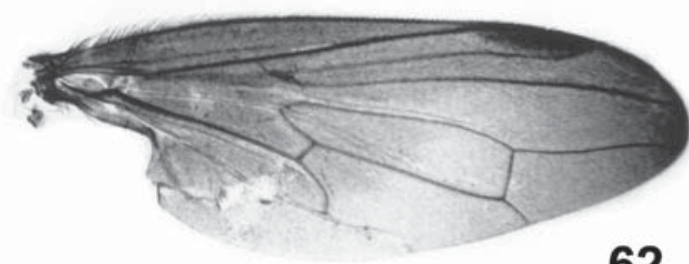

62

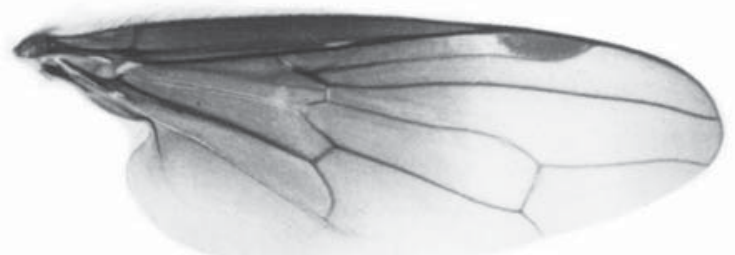

63
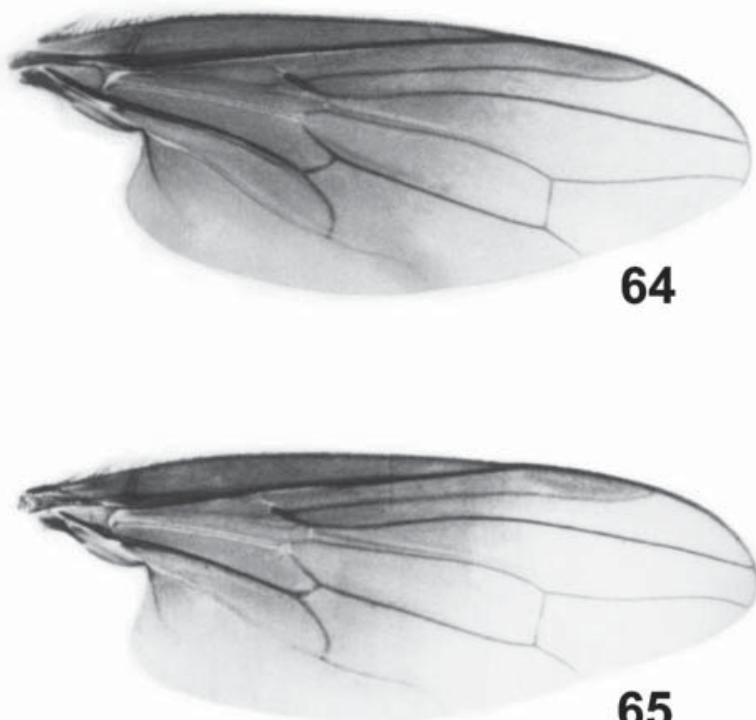

65
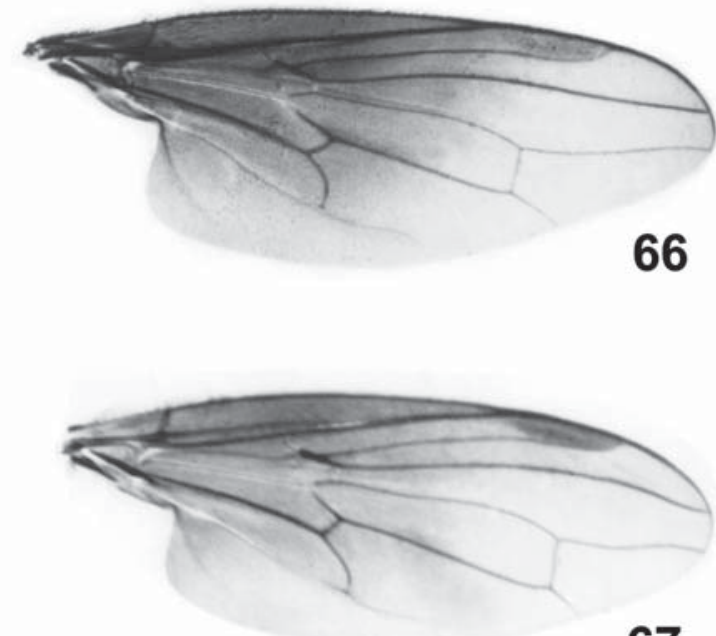

67
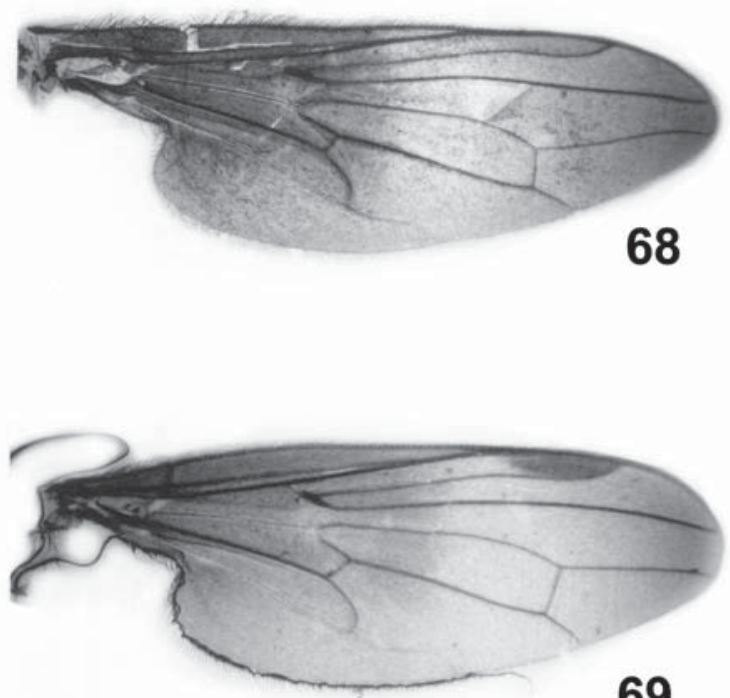

69

Figs. 62-69. Asas (dimensões em mm, entre parênteses): 62, E fuscipennis sp. nov., holótipo $\sigma^{7}(4,6) ; 63$, E. grandis sp. nov.,

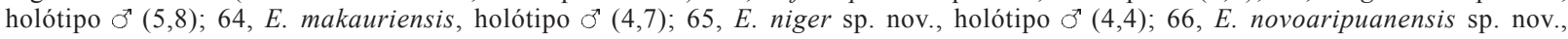
parátipo o $(4,6) ; 67$, E. piceus (Wiedmann, 1830) (3,6); 68, E. reduncus sp. nov., holótipo o $(4,2) ; 69$, E. tomentosus sp. nov., holótipo ơ $(4,0)$.

uma série dupla na porção mediana do fêmur; série PV com 13 cerdas espiniformes sendo as duas apicais mais recuadas para a face ventral que as demais. Tíbia posterior com uma cerda D pré-apical discretamente destacada. Primeiro tarsômero posterior com um espinho A apical.

Abdômen 2,6 vezes mais longo que o tórax; castanho a castanho-escuro com cerdas amarelas, longas e densas no tergitos 1-3; cerdas dorsais inconspícuas; brilhante, exceto o $\mathrm{Tg} 8 \mathrm{com}$ pruinosidade fina castanha. Terminália (figs. 54-58): surstilo direito longo, maior que metade do comprimento do epândrio, levemente curvado para dentro; surstilo esquerdo com ápice largo e truncado.

Fêmea. Semelhante ao macho, exceto: fêmur posterior delgado com cerdas mais espaçadas, 6 cerdas $\mathrm{AV}$; série $\mathrm{V}$ com 12 espinhos curtos ocupando os $2 / 3$ apicais do fêmur; série PV com 3 cerdas espiniformes próximas do ápice. Ovipositor como nas figuras 59-61 .

Material-tipo. Holótipo ơ, BRASIL, Paraná: Umuarama, 07-13.IX.1980, Armadilha Malaise, A. Yamamoto col. (INPA) (em bom estado, não dissecado). Parátipos. Mesmos dados do holótipo, 2 \&, 10.X.1980; ơ, 12-18.X.1980; 3 \&, 19-25.X.1980 (INPA); São Paulo: Barueri, đ', 2.XII.1954; ð, 8.X.1955, K. Lenko col. (MZSP).

Distribuição. Brasil (São Paulo, Paraná).

Discussão. E. tomentosus sp. nov. e E. piceus são as únicas espécies deste grupo com o escuto pruinoso dorsalmente. Diferem entre si pela terminália masculina. Em E. tomentosus sp. nov., o surstilo direito é longo e articulado, com ápice inteiro, o surstilo esquerdo tem ápice truncado e o lobo hipandrial é estreito. Difere das espécies com surstilo direito longo de acordo com o discutido em E. reduncus sp. nov. e E. niger sp. nov. 
Etimologia. O nome específico se refere à pruinosidade do tórax.

Agradecimentos. A José Albertino Rafael (INPA), John Chainey (BMNH), Ubirajara Martins (MZSP), David Grimaldi (AMNH), Inocêncio Gorayeb (MPEG) e Hubert Schumann (ZMHU), pelo empréstimo dos tipos e espécimes de Euhybus.

\section{REFERÊNCIAS BIBLIOGRÁFICAS}

Ale-Rocha, R. 2002. Revisão do gênero Euhybus Coquillett (Diptera, Empididae, Hybotinae) da Região Neotropical. Grupo dimidiatus. Acta Amazonica, Manaus, 32(2):299-324.

Ale-Rocha, R. \& Carvalho, C. J. B. 2003. Neohybos gen. nov. (Diptera, Empidoidea, Hybotinae) from the Neotropical Region. Zootaxa, Aukland, 387:1-16.

Becker, T. 1919. Diptères, Brachycères. In: Mission de L'Arc Méridien en Amerique du Sud. Paris, v.10, p.163-215.

Bezzı, M. 1909. Beitraege zur Kenntniss der südamerikanischen Dipterenfauna. Fam. Empididae. Nova Acta LeopolinoCarolinae, Halle, 91:297-406.

Coquillett, D. W. 1895. Revision of the North America Empidae - A family of two-winged flies. Proceedings of the United States National Museum, Washington, 18:387-440.

Cumming, J. M. 1992. Lactic acid as an agent for macerating Diptera specimens. Fly Times, Ottawa, 8:7.

Cumming, J. M.; Sinclair, B. J. \& Wood, D. M. 1995. Homology and phylogenetic implications of male genitalia in DipteraEremoneura. Entomologica Scandinavica, Copenhagen, 26:121-152.

Curran, C. H. 1931. New species of Empididae from Panama. American Museum Novitates, New York, 467:1-12.

McAlpine, J. F. 1981. Morphology and terminology. In: McAlpine, J. F.; Peterson, B. V. et al. eds. Manual of Nearctic Diptera. Ottawa, Res. Branch. Agriculture Canada. v.1, p.9-63 (Monograph 27).

Melander, A. L. 1902. Monograph of North American
Empididae. Part 1. Transactions of the American Entomological Society, Philadelphia, 28:195-367.

1927. Diptera, Fam. Empididae. In: Wystman, P. ed. Genera Insectorum. Bruxelles, v.185, 434p.

1965. Family Empididae (Empidae, Hybotidae). In: Stone, A.; Sabrosky, C. W. et al. eds. A catalog of the Diptera of America North of Mexico. Washington, U.S. Depart. Agric. v.276, p.446-481.

Rafael, J. A. \& Ale-Rocha, R. 1995. Revisão das espécies neotropicais de Empididae (Diptera) descritas por Mario Bezzi. I. Hybotinae. Revista Brasileira de Entomologia, Curitiba, 39(3):517-546.

Sмiтh, K. G. V. 1962. Studies on the Brazilian Empididae (Diptera). Transactions of the Royal Entomological Society of London, London, 114:195-266.

1963. The Empididae (Diptera) collected on the Oxford University expeditions to British Guiana in 1929 and 1937. Proceedings of the Entomological Society of London, Series B, London, 32:153-161.

1964. Lectotype designation and redescription of two Wiedemann species of Brazilian Empididae (Diptera), with new synonymy. Proceedings of the Entomological Society of London, Series B, London, 33(3-4):50-52.

1967. Family Empididae (Empidae, Hybotidae). In: Papalero, N. ed. A catalogue of Diptera of Americas South of the United States. São Paulo, Departamento de Zoologia, Secretaria de Agricultura. v.39, 67p.

WALKER, F. 1849. List of the specimens of dipterous insects in the collection of the British Museum. London. v.3, 687p.

1852. Diptera. In: SAunders, W. W. ed. Insecta Saundersiana: or characters of undescribed insects in the collection of W.W. Saunders. London, 474p.

Wheeler, W. M. \& Melander, A. L. 1901. Hybotinae. In: Godman, F. D. \& Salvin, O. eds. Biologia CentraliAmericana, Insecta. Diptera. London, v.1, p.214-216. (Supplement).

Wiedemann, C. R. W. 1830. Aussereuropäische zweiflugelige Insekten. Hamm, Schulzischen Buchhandlung. v. $2,684 \mathrm{p}$.

Recebido em dezembro de 2003. Aceito em agosto de 2004. ISSN 0073-4721 